\title{
Fungsionalisasi Limbah Cair Industri Tahu Tradisional PRIMKOPTI Jakarta Barat Sebagai Media Tumbuh Spirulina platensis
}

\author{
Nita Noriko ${ }^{1 *}$, Agus Masduki $^{2}$, Analekta Tiara Perdana $^{3}$, Eka Mudrikah $^{4}$, Eka Primasatya $^{5}$, Margo \\ Sulistio $^{6}$, Siti Fauzia Canadianti ${ }^{7}$ \\ 1,2,3,4,5,6,7) Program Studi Biologi (Bioteknologi), Fakultas Sains dan Teknologi, \\ Universitas Al Azhar Indonesia, Jl. Sisingamangaraja, Jakarta 12110 \\ Tlp. 7244456, Fax. 7244767, *penulis untuk korespondensi: nita_noriko@uai.ac.id
}

\begin{abstract}
Tofu industry produce organic waste in the form of liquid and solid. But, most of the industry cast away its waste to the surroundings directly without any processes before and contaminate the environment. One way out to solve this problem is by functionalizing the liquid waste as growth media of Spirulina platensis. In this research, exemic culture method with independent microalgae is used. Based on the result of the research, the optimal growth of Spirulina platensis if cultured in $10 \%$ concentration of liquid waste with $4: 6$ comparison $(400 \mathrm{ml}$ Spirulina platensis : $600 \mathrm{ml}$ tofu liquid waste). It is indicated by green color intensity of Spirulina platensis.
\end{abstract}

Keywords - functionalization, waste, Spirulina latensis, growth media

\section{PENDAhuluan}

$\mathrm{T}$ ahu adalah salah satu produk makanan yang berbahan dasar kedelai. Selain begizi tinggi, tahu juga mudah didapat dengan harga yang terjangkau. PRIMKOPTI (Primer Koperasi Tahu Tempe Indonesia) yang terletak di Semanan Jakarta Barat adalah salah satu kawasan industri tahu tempe tradisional. Total pengrajin tahu tempe yang tergabung dalam PRIMKOPTI berjumlah 749 orang. Jumlah pengrajin tahu tempe tersebut cukup banyak, dan tentunya demikian juga dengan limbah yang dihasilkan.

Pengolahan kedelai menjadi tahu membutuhkan jumlah air yang sangat banyak. Oleh karena banyaknya penggunaan air, industri tahu menghasilkan banyak limbah organik cair. Namun, hal yang paling disayangkan adalah kebanyakan industri tersebut membuang limbahnya secara langsung, sehingga dapat mencemari lingkungan. Oleh sebab itu, pemanfaatan dan pengolahan limbah yang baik dan benar sangat diperlukan. Salah satu jalan keluar untuk mengatasi masalah pencemaran oleh limbah cair hasil industri tahu di PRIMKOPTI yaitu dengan fungsionalisasi limbah cair tersebut sebagai media pertumbuhan Spirulina platensis.

Berbagai zat gizi banyak dikandung oleh alga dari kingdom protista ini (Kabinawa;2006), seperti protein yang mencapai $72 \%$, lipid $8 \%$, karbohidrat $16 \%$, vitamin B1, B2, B6, B12, C, niasin, $\beta$ karotin dan kandungan asam amino yang cukup seimbang. Alga yang juga mengandung salah satu asam lemak esensial yaitu asam $\gamma$-linoleat (GLA) yang merupakan salah satu sumber energi alternatif. Selain itu Spirulina platensis mudah dikultur dan dapat berkembang biak dengan cepat. Dengan fungsionalisasi limbah cair industri tahu ini diharapkan dapat mengurangi pencemaran lingkungan serta dapat menghasilkan Spirulina platensis yang memiliki banyak kegunaan.

Pengembangan Spirulina dipengaruhi beberapa faktor.Faktor tersebut adalah suhu berkisar diantara 35-37 Celcius dan suhu minimum 19-20 Celcius, pupuk majemuk yaitu N:P:K(20:20:20), $\mathrm{NaHCO}_{3}$.sodium karbonat ini berfungsi untuk mempertahankan $\mathrm{pH}$, mikronutrient-mikronutrien, pH berkisar diantara 8-11, intensitas cahaya 20 dan 30 candela (Kabinawa;2006).

\section{LANDASAN TEORI}

Fungsionalisasi adalah hal menjadikan berfungsi atau pemfungsionalan (Tim Penyusun Kamus Pusat Pembinaan dan Pengembangan Bahasa, 1991:282). Fungsionalisasi yang akan peneliti lakukan adalah fungsionalisasi limbah cair industri tahu tradisional 
PRIMKOPTI Jakarta Barat. Limbah cair adalah semua limbah yang berbentuk cairan atau berada dalam fase cair (Wahyuni, 2009). Limbah cair industri tahu mengandung senyawa organik yang tinggi (Darsono, 2009). Apabila tidak diolah dengan baik, limbah tersebut akan menyebabkan polusi air dan udara. Sebagian besar industri tahu tradisional tidak memiliki pengolahan limbah cair yang baik. Oleh karena itu, limbah cair tersebut akan difungsionalisasi menjadi media pertumbuhan Spirulina platensis.

Limbah cair yang dihasilkan berbentuk cairan kental dan disebut air dadih. Air dadih mengandung protein yang tinggi. Limbah ini dibuang secara langsung sehingga menghasilkan bau yang mencemari lingkungan. Limbah cair tersebut dapat juga berasal dari pencucian kedelai, pemasakan kedelai, pencucian peralatan proses, pencucian lantai dan pemasakan serta larutan bekas rendaman kedelai. Karakteristik fisika dan kimia limbah cair tersebut juga perlu diperhatikan, karena pada limbah tersebut mengandung berbagai macam bahan organik yang dapat diuraikan ( Pamungkas . 2005).

Pengembangan Spirulina dipengaruhi beberapa faktor yaitu suhu, pupuk, $\mathrm{pH}, \mathrm{NaHCO}_{3}$ mikro dan makronutrien, intensitas cahaya. Suhu yang dibutuhkan berkisar diantara 35-37 Celcius dan suhu minimum 19-20 Celcius. Perbandingan pupuk majemuk yaitu adalah N: P: K (20:20:20). Disamping itu dibutuhkan $\mathrm{NaHCO}_{3}$ (sodium karbonat) yang berfungsi untuk mempertahankan pH 8 sampai 11 dan intensitas cahaya 20 sampai 30 Candela. Klasifikasi Spirulina adalah sebagai berikut.

$\begin{array}{lll}\text { Kingdom } & : & \text { Protista } \\ \text { Divisi } & : & \text { Cyanophyta } \\ \text { Kelas } & : & \text { Cyanophyceae } \\ \text { Ordo } & : & \text { Nostocales } \\ \text { Famili } & : & \text { Oscilatoriaceae } \\ \text { Genus } & : & \text { Spirulina } \\ \text { Spesies } & : & \text { Spirulina platensis }\end{array}$

Spirulina memiliki beberapa tahap pertumbuhan saat dikultur yaitu fase Pertumbuhan Lag (Adaptasi), dilanjutkan dengan akselerasi dan logaritmik, pertumbuhan deselerasi, pertumbuhan stasioner dan kematian. Pada fase Pertumbuhan Lag (Adaptasi) inokulum baru ditransfer ke medium pengkulturan dan mulai beradaptasi dengan lingkungan medium tumbuhnya. Fase ini terjadi sekitar 10 jam setelah inokulasi. Fase Pertumbuhan Akselerasi adalah fase inokulum sudah memanfaatkan nutrisi yang terkandung di dalam medium sehingga dapat bereproduksi menjadi lebih banyak. Sedangkan fase Pertumbuhan Logaritmik sel inokulum sudah membelah secara maksimal menjadi 2 kali lipat dari sebelumnya (doubling time). Pada fase ini perbanyakan sel inokulum berbanding lurus dengan proses fotosintesis dan biosintesis sel. Fase ini terjadi sekitar 30-40 jam setelah pengkulturan. Pada fase ini pula inokulum biak sangat tepat dimasukkan ke dalam medium pertumbuhan baru. Fase pertumbuhan deselerasi (Deklinasi) adalah fase pertumbuhan sel mulai terhambat karena keterbatasan medium pertumbuhan mulai terjadi. Konsentrasi $\mathrm{CO}_{2}, \mathrm{~N}$ dan $\mathrm{P}$ yang bertugas sebagai hara pemacu pertumbuhan berkurang konsentrasinya. Fase Pertumbuhan Stasioner adalah pertumbuhan sel inokulum konstan. Konsentrasi biomassa maksimal terjadi pada fase ini, sedangkan parameter lainnya fluktuatif. Sedangkan pada fase kematian terjadi penurunan sel inokulum secara drastis. Jika diamati di bawah mikroskop, sel terlihat pecah dan mati. Kultur berwarna kehijauan, kemudian berubah menjadi hijau kekuningan, lalu memucat dan mati (Kabinawa,2006)

\section{METODE PENELITIAN}

Alga Spirulina platensis diperoleh dari Laboratorium Biologi Universitas Al Azhar Indonesia yang kemudian ditumbuhkan di dalam Laboratorium Kimia dengan menggunakan Erlenmeyer $500 \mathrm{~mL}, \mathrm{pH} 9,5$, penyinaran dengan menggunakan lampu TL 36 watt serta menggunakan aerator. Pertumbuhan Spirulina platensis dilihat dari adanya perubahan intensitas warna yang ditimbulkan. Kematian Spirulina platensis dilihat dari adanya perubahan warna dari hijau menjadi kecoklatan.

Spirulina platensis dikultur dengan lima perlakuan yaitu ,

Kultur I

(kontrol) : ditanam dalam air yang mengandung 0.075\% NPK (medium kontrol), dengan perbandingan subkultur Spirulina platensis dan medium kontrol (4:6), dan pemberian $\mathrm{NaOH} 1 \%$ secukupnya untuk mempertahankan $\mathrm{pH}$ medium 9,5.

Kultur II : ditanam dalam medium (10\% limbah cair industri tahu dan $90 \%$ air) dengan subkultur 4:6 dan pemberian $\mathrm{NaOH} 1 \%$ secukupnya untuk mempertahankan $\mathrm{pH}$ medium 9,5. 
Kultur III : ditanam dalam medium (10\% limbah cair industri tahu dan $90 \%$ air), dengan subkultur 1:10 dan pemberian $\mathrm{NaOH} \quad 1 \%$ secukupnya untuk mempertahankan $\mathrm{pH}$ medium 9,5.

Kultur IV : ditanam dalam medium (20\% limbah cair industri tahu dan $80 \%$ air), dilakukan subkultur 4:6 dan pemberian $\mathrm{NaOH} 1 \%$ secukupnya untuk mempertahankan $\mathrm{pH}$ medium 9,5 .

Kultur V : ditanam dalam medium (20\% limbah cair industri tahu dan $80 \%$ air), dilakukan subkultur 1:10 dan pemberian $\mathrm{NaOH} 1 \%$ secukupnya untuk mempertahankan $\mathrm{pH}$ medium 9,5 .

\section{HASIL DAN PEMBAHASAN}

Hasil kultur Spirulina platensi pada medium kontrol NPK dengan konsentrasi $0.5 \%, 0.25 \%$, dan $0.075 \%$ memperlihatkan pertumbuhan. Berdasarkan pengamatan warna, pertumbuhan Spirulina platensis yang optimum terdapat pada konsentrasi NPK $0.075 \%$. Dengan demikian, medium dengan konsentrasi NPK $0.075 \%$ dijadikan rujukan sebagai medium kontrol (Kultur I). Percobaan kultur yang menggunakan media limbah $100 \%$ dengan perbandingan 1:1 tidak memperlihatkan pertumbuhan Spirulina platensis. Kondisi ini kemungkinan disebabkan oleh $\mathrm{pH}$ medium limbah yang semakin asam, karena syarat pertumbuhan Spirulina platensis membutuhkan $\mathrm{pH}$ basa 9,5 - 11 seperti yang dikemukakan oleh (Angka dan Suhartono, 2000). Pada perlakuan ini, terjadi perubahan intensitas warna Spirulina platensis yang pada awalnya hijau berubah menjadi kuning (memudar). Data tersebut menjadi acuan untuk menentukan prosentase limbah cair tahu dalam kultur Spirulina platensis dan juga dalam pemberian $\mathrm{NaOH}$ untuk menstabilkan $\mathrm{pH}$ medium limbah tahu.

Hasil pengamatan terhadap intensitas warna pada kultur Spirulina platensis, menunjukkan bahwa Spirulina platensis dapat tumbuh pada medium, baik pada kultur I,II,III, dan IV dengan intensitas warnanya berbeda. Penggunaan media limbah $10 \%$ dengan perbandingan 4:6, memperlihatkan pertumbuhan Spirulina platensis yang optimal sebagai indikasi pertumbuhan dan aktifitas fotosintesis (Gambar 2). Hal ini juga dikemukakan oleh Chisty (2007) bahwa mikroalgae memiliki kemampuan untuk fotosintesis. Pada perlakuan ini ditunjukkan dengan intensistas warna hijau Spirulina platensis yang semakin pekat. Kultur pada medium limbah $10 \%$ dengan perbandingan 1:10 juga memperlihatkan pertumbuhan dengan warna hijau walaupun tidak terlihat pekat (Gambar 3). Penelitian juga menunjukkan kultur yang menggunakan medium limbah dengan konsentrasi $20 \%$ dan perbandingan 1:10 memperlihatkan Spirulina platensis yang dapat tumbuh akan tetapi tidak menunjukkan warna hijau yang jelas (Gambar 4), sedangkan pada konsentrasi 20\% dan perbandingan 4:6 Spirulina platensis tidak dapat tumbuh (Gambar $5)$.

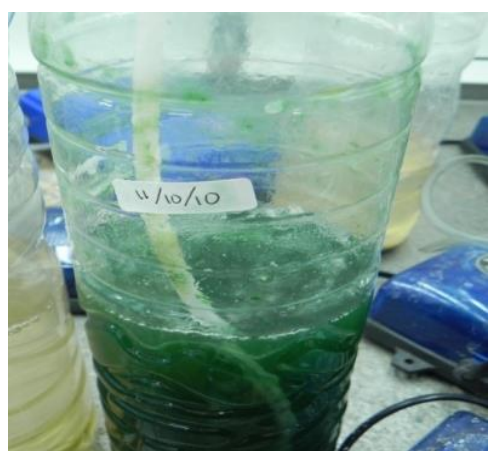

Gambar 1.Spirulina platensis pada Kultur I

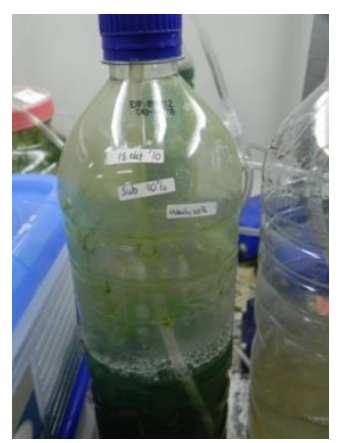

Gambar 2.

Spirulina plantesis Kultur II (10\%, 4:6)

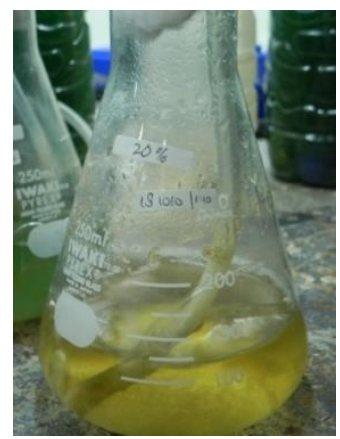

Gambar 4.

Spirulina platensis

Kultur IV (20\%, 1:10)

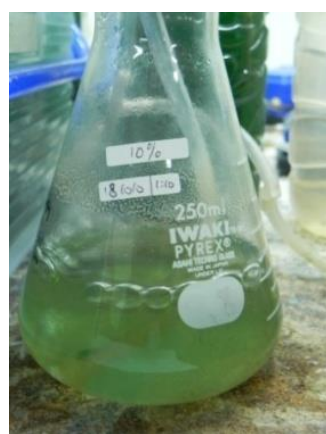

Gambar 3. Spirulina plantesis Kultur III $(10 \%, 1: 10)$

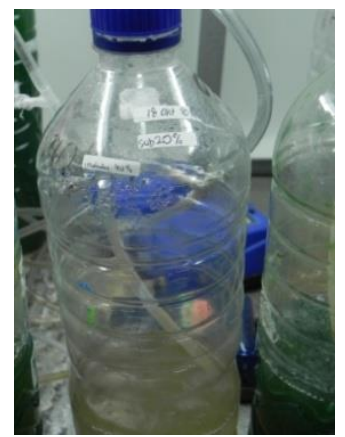

Gambar 5.

Spirulina plantesis Kultur V (20\%, 4:6 


\section{KESIMPULAN}

Spirulina platensis dapat tumbuh optimum pada kondisi laboratorium dengan konsentrasi NPK $0,075 \%$ dengan dan medium kontrol (4: 6), disamping itu juga pada medium limbah industri tahu 10\% dengan perbandingan (4:6) serta pada intensitas cahaya lampu TL 36 Watt.

\section{UCAPAN TERIMAKASIH}

Terimakasih kami sampaikan kepada Lembaga Pengkajian dan Pengembangan Pendidikan Penelitian dan Pengabdian masyarakat (LP5M), Universitas Al Azhar Indonesia Penelitian yang telah mendanai penelitian ini sehingga penelitian dapat dilaksanakan. Terimakasih pula kami mengucapkan kepada mahasiswa Prodi Biologi (Bioteknologi) yang turut melakukan penelitian ini.

\section{DAFTAR PUSTAKA}

[1] Angka ST dan Suhartono MT. 2000. Bioteknologi Hasil Laut. Bogor : Pusat Kajian Sumberdaya Pesisir dan Lautan, Institut Pertanian Bogor

[2] Chisty, Y. 2007. Biodiesel from Microalgae. Biotechnology Advances $25: 294-306$

[3] Darsono, V. 2007. Pengolahan Limbah Cair Tahu Secara Anerob dan Aerob. Yogyakarta: Program Studi Teknik Industri Fakultas Teknik Industri Universitas Atmajaya

[4] Kabinawa, K. 2006. Spirulina Ganggang Penggempur Aneka Penyakit. Jakarta: Agromedia Pustaka

[5] Pamungkas E. 2005. Pengolahan limbah cair PT. Pupuk Kujang dengan Spirulina pada reaktor curah (Batch). Bogor : Program studi Teknologi Hasil Perairan, Fakultas Perikanan dan Ilmu Kelautan, Institut Pertanian Bogor

[6] Tim Penyusun Kamus Pusat Pembinaan dan Pengembangan Bahasa. 1991:282. Kamus Besar Bahasa Indonesia. Jakarta : Balai Pustaka

[7] Wahyuni. 2009. Biogas. Jakarta: Agromedia Pustaka 